\title{
The mRNA for Elongation Factor $1 \alpha$ Is Localized in Dendrites and Translated in Response to Treatments That Induce Long-Term Depression
}

\author{
Fen Huang, ${ }^{1}$ Jennifer K. Chotiner, ${ }^{1}$ and Oswald Steward ${ }^{1,2}$ \\ ${ }^{1}$ Reeve-Irvine Research Center, Departments of Anatomy and Neurobiology, Neurobiology and Behavior, and Neurosurgery, and ${ }^{2}$ Center for the \\ Neurobiology of Learning and Memory, University of California at Irvine, Irvine, California 92697
}

\begin{abstract}
There is increasing evidence that long-lasting forms of activity-dependent synaptic plasticity, such as long-term potentiation (LTP) and long-term depression (LTD), require local synthesis of proteins within dendrites. Identifying novel dendritic mRNAs and determining how their distribution and translation is regulated is a high priority. We demonstrate here that the mRNA for the elongation factor $1 \alpha$ $(\mathrm{EF} 1 \alpha)$ is present in vivo in the dendrites of neurons that exhibit LTP and LTD, and that its translation is locally regulated. The subcellular distribution of EF $1 \alpha$ mRNA differs from any of the dendritic mRNAs that have been described previously. In the hippocampus, the mRNA is highly expressed in cell bodies and is also concentrated in the zone of termination of commissural/associational afferents in the inner molecular layer, suggesting that mRNA localization is in some way related to the distribution of different types of synapses. Nevertheless, the localization of EF1 $\alpha$ mRNA is not altered by prolonged periods of synaptic activation that are sufficient to cause a dramatic redistribution of Arc mRNA. Local application of the metabotropic glutamate receptor agonist $(R, S)$-3,5-dihydroxyphenylglycine (DHPG) led to dramatic increases in immunostaining for EF1 $\alpha$ protein in dendrites, and treatment of hippocampal slices with DHPG, which is known to induce LTD, led to increases in EF1 $\alpha$ protein levels. Both responses were blocked by the protein synthesis inhibitor anisomycin. In contrast, stimulation of the perforant path using patterns of stimulation that induce LTP caused rapid increases of immunostaining for EF1 $\alpha$ protein in the activated dendritic lamina, but these increases were not blocked by anisomycin or rapamycin. The findings suggest that local synthesis of EF1 $\alpha$ protein may be important for the synaptic mechanisms that underlie protein synthesis-dependent LTD.
\end{abstract}

Key words: LTP; LTD; synaptic plasticity; protein synthesis; dendrite; mouse; rat; dendritic mRNA; polyribosomes; metabotropic glutamate receptors; mGluRs

\section{Introduction}

Activity-dependent synaptic modifications, such as long-term potentiation (LTP) and long-term depression (LTD), are thought to be a molecular mechanism for learning and memory (Bliss and Collinridge, 1993; Bailey et al., 1996; Kandel, 2001). The late phase of LTP and the induction of LTD depend on protein synthesis, and there is increasing evidence that a critical component of this synthesis occurs locally in dendrites (Steward and Schuman, 2003; Bailey et al., 2004; Kelleher et al., 2004a,b). In addition, recent studies have revealed that a form of LTD induced by metabotropic glutamate receptor (GluR) agonists depends on protein synthesis for induction (Huber et al., 2000). Identifying mRNAs that are present in the dendrites of neurons that exhibit LTP and LTD and that are available for local translation is a high priority.

Received May 3, 2005; revised June 24, 2005; accepted June 24, 2005

This work was supported by National Institutes of Health Grant NS12333 (0.S.). Thanks to Dr. C. Gall for providing sections prepared by the Timm's sulfide silver technique.

Correspondence should be addressed to Dr. Oswald Steward, 1105 Gillespie Neuroscience Research Facility, 837 Health Sciences Drive, University of California at Irvine, Irvine, CA 92697. E-mail: osteward@uci.edu.

DOI:10.1523/JNEUROSCI.1779-05.2005

Copyright $\odot 2005$ Society for Neuroscience $\quad$ 0270-6474/05/257199-11\$15.00/0
In considering the significance of dendritic protein synthesis, it seems reasonable to focus on mRNAs that are present at relatively high levels (i.e., detectable by in situ hybridization) and that are present in middle and distal dendrites, in which most synaptic connections are made. There are currently $\sim 20$ mRNAs that fit these criteria (for a recent review, see Steward and Schuman, 2003), the most recent addition being a transcript encoding one of the isoforms of SAPAPs (synapse-associated protein 90/ postsynaptic density 95-associated proteins) (Welch et al., 2004 and Kindler et al., 2004).

Hints about possible new candidates have come from recent evidence that the mRNA encoding elongation factor $1 \alpha(\mathrm{EF} 1 \alpha)$ is present in Aplysia neurites and is locally translated. In Aplysia, levels of EF $1 \alpha$ mRNA increase in neurites when serotonin is applied to the Aplysia sensory neuron to induce long-term facilitation (Giustetto et al., 2003). EF1 $\alpha$ is one of the key components of translational machinery and is part of the elongation factor 1 complex, which includes EF- $1 \beta$ and EF- $1 \gamma$. EF $1 \alpha$ promotes GTP-dependent binding of aminoacyl-tRNA to the ribosome during peptide elongation. Thus, local synthesis of this component of the translational machinery is an intriguing potential mechanism for regulating overall translational capacity at synaptic sites (Bailey et al., 2004). 
Based on this background, the present study assessed whether the mRNA for EF1 $\alpha$ is present in the dendrites of mammalian neurons in vivo that exhibit LTP and LTD, and whether its localization or translation is altered by signals that induce LTP or LTD. Using in situ hybridization, immunocytochemistry, and biochemical techniques, we demonstrate that EF1 $\alpha$ mRNA is present in dendrites of mammalian neurons in vivo. It is especially prominent in dendrites of young animals, and, in mature animals, it is concentrated in laminas that correspond to sites of termination of particular afferent systems (the commissural/ associational system in the dentate gyrus). Neither the levels nor the distribution of the mRNA is altered by prolonged periods of intense synaptic activity that induce LTP, indicating that mRNA distribution in dendrites is relatively stable. Also, induction of LTP does not lead to new EF1 $\alpha$ protein synthesis in dendrites, whereas pharmacological activation of mGluRs triggers dramatic increases in EF1 $\alpha$ synthesis within dendrites. Nevertheless, the increases in EF1 $\alpha$ levels in dendrites did not lead to a detectable increase in translational activity as measured by protein precursor incorporation, suggesting that the increase in $\mathrm{EF} 1 \alpha$ protein levels are important for something other than regulating translational capacity.

\section{Materials and Methods}

Preparation of EF1 $\alpha$ cRNA probes. The EF1 $\alpha$ cDNA used to generate cRNA probes for in situ hybridization is a $392 \mathrm{bp}$ fragment, which is complementary to the $799-1190$ portion of the $1.7 \mathrm{~kb}$ EF $1 \alpha$ mRNA. The primers used to clone the cDNA from mouse brain total RNA were as follows: sense, 5' GCATCCTACCACCAACTCGT 3'; antisense, 5' CGTGTGGCAATCCAATACAG 3'.

The cDNA was subcloned into the EcoR1-XhoI sites of the pBluescript-SK II plasmid and linearized with EcoR1 for antisense cRNA probe synthesis. For in situ hybridization, digoxigenin-labeled antisense RNA probes were produced by in vitro transcription from the T7 promoter as described previously (Steward et al., 1998).

Neurophysiologic techniques and stimulation paradigms. The techniques for activating perforant path projections to the dentate gyrus were as described previously (Steward et al., 1998). Briefly, adult male rats were anesthetized with urethane. A stimulation electrode was placed in the medial entorhinal cortex, and a recording electrode was positioned in the dentate gyrus. Recording electrodes were filled with $0.9 \%$ saline or drugs as described further below. For the experiments involving stimulation paradigms that induce LTP, stimulus intensity was adjusted so as to elicit a $1.5-3.0 \mathrm{mV}$ population spike. Test stimulation was delivered to determine the baseline response amplitude, and then trains of highfrequency stimuli (eight pulses at $400 \mathrm{~Hz}$ ) were delivered at a rate of one every $10 \mathrm{~s}$ for different periods (three bouts of 10 trains each at $400 \mathrm{~Hz}$ over $5 \mathrm{~min}$ to induce LTP, or one train every $10 \mathrm{~s}$ for $15 \mathrm{~min}, 30 \mathrm{~min}, 1 \mathrm{~h}$, and $2 \mathrm{~h}$ ). Ten test stimuli were delivered after each of the first three bouts of 10 trains to assess the degree of LTP (see Fig. $4 F$ ).

For experiments involving local delivery of drugs to the hippocampus, drugs were delivered in one of two ways: (1) by filling the micropipette recording electrode with the drug solutions and allowing the drug to diffuse from the pipette (Steward and Halpain, 1999; Steward and Worley, 2001a); or (2) by injecting via a $10 \mu \mathrm{l}$ Hamilton microsyringe fitted with a pulled glass micropipette. Injections were centered in the stratum radiatum/stratum lacunosum-moleculare junction based on evoked responses generated by perforant path stimulation. For experiments involving pressure injections of drugs (see below), recordings were made by attaching leads directly to the metal barrel of a Hamilton microsyringe fitted with a pulled glass micropipette tip.

The following agents were dissolved in saline and delivered locally by diffusion from a micropipette recording electrode: $(R, S)-3,5$ dihydroxyphenylglycine (DHPG) $(5-10 \mathrm{mg} / \mathrm{ml})$, anisomycin $(25 \mathrm{mg} /$ $\mathrm{ml})$, and latrunculin B $(400 \mu \mathrm{g} / \mathrm{ml})$. Rapamycin $(50 \mathrm{mg} / \mathrm{ml})$ was dissolved in $10 \%$ DMSO and was injected using the Hamilton microsyringe/ micropipette combination. To block protein synthesis systemically, anisomycin was administered subcutaneously (100 mg/kg) $30 \mathrm{~min}$ before DHPG application. Physiological responses induced by stimulating the entorhinal cortex were recorded before and after drug delivery.

Preparation of tissue for in situ hybridization and immunostaining. At the termination of the neurophysiologic experiments, rats were deeply anesthetized and then perfused with $4 \%$ paraformaldehyde in $0.1 \mathrm{M}$ PBS, $\mathrm{pH}$ 7.4. Adult C57BL/6 mice and developing mice $(10,15,25$, and $39 \mathrm{~d}$ of age) were perfused in the same way. Brains were removed and postfixed overnight in $4 \%$ paraformaldehyde/PBS. Brains that were to be sectioned on a cryostat were placed in $30 \%$ sucrose in $0.1 \mathrm{~m}$ PBS $(0.1 \%$ DEPC treated) until the brains sank and were then embedded in Tissue Tec OCT compound and frozen on dry ice. Frozen brains were sectioned at $20 \mu \mathrm{m}$ on a cryostat, and sections were thaw mounted on poly-L-lysinecoated slides (stored at $-80^{\circ} \mathrm{C}$ ) or floating in $1 \times \mathrm{PBS}$ (stored at $4^{\circ} \mathrm{C}$ ). For immunocytochemistry, brains were sectioned on a vibratome at $40 \mu \mathrm{m}$ and stored in $1 \times \mathrm{PBS}$ at $4^{\circ} \mathrm{C}$.

In situ hybridization. For in situ hybridization, slides were thawed at room temperature for 5-10 min and were then dried in a $42^{\circ} \mathrm{C}$ oven for $10 \mathrm{~min}$. Sections were postfixed with $4 \%$ paraformaldehyde in $0.1 \mathrm{M}$ PBS for $30 \mathrm{~min}$ and then rinsed with $0.5 \times$ SSC $(0.1 \%$ DEPC treated $)$ for 5 min. Sections were treated with Proteinase K $(1.25 \mathrm{mg} / \mathrm{L})$ for $30 \mathrm{~min}$, rinsed again with $0.5 \times$ SSC $(0.1 \%$ DEPC treated) for $10 \mathrm{~min}$, and air dried. The sections were covered with $75 \mu$ l of prehybridization buffer ( $2 \times$ SSC, $25 \%$ formamide, $1 \%$ Denhardt's reagent, $10 \%$ dextran sulfate, $0.5 \mathrm{mg} / \mathrm{ml}$ heparin, $0.5 \mathrm{mg} / \mathrm{ml}$ yeast tRNA, and $0.25 \mathrm{mg} / \mathrm{ml}$ denatured salmon sperm DNA) and incubated at $42^{\circ} \mathrm{C}$ for $2 \mathrm{~h}$. After the prehybridization, $\sim 0.5 \mu \mathrm{g}$ of digoxigenin-cRNA probe in $75 \mu \mathrm{l}$ of hybridization buffer was added to each section. The sections were covered with a baked coverslip and incubated overnight at $55^{\circ} \mathrm{C}$ in humidified box with $25 \%$ formamide $2 \times$ SSC. The next day, the coverslips were removed and sections were washed with $2 \times$ SSC/10 mM EDTA twice (10 min each). The sections were treated with RNaseA for $30 \mathrm{~min}$ and then washed twice with $2 \times$ SSC/EDTA (10 min per wash). The stringency wash was $0.5 \times$ SSC $/ 10 \mathrm{~mm}$ EDTA at $55^{\circ} \mathrm{C}$ for $2 \mathrm{~h}$. After that, sections were washed with $0.5 \times$ SSC twice (10 min each at room temperature). Alkaline phosphatase-conjugated anti-digoxigenin Fab fragment (1:5000) was used to detect the hybridized probes. Nitroblue-tetrazolium-chloride/5bromo-4-chlor-indolyl-phosphate solution was applied overnight at $4^{\circ} \mathrm{C}$ to detect the alkaline phosphatase. Sections were then washed with 100 mM Tris- $\mathrm{HCl}(\mathrm{pH} 8.5) / 1 \mathrm{~mm}$ EDTA three times for $10 \mathrm{~min}$ each. Then slides were briefly rinsed with nanopure water twice and covered with Kaiser's glycerol jelly.

Immunohistochemistry. For antigen retrieval, free-floating sections were heat treated at $95^{\circ} \mathrm{C}$ for $5 \mathrm{~min}$ or treated with $5 \mu \mathrm{g} / \mathrm{ml}$ proteinase $\mathrm{K}$ for $15 \mathrm{~min}$ at $37^{\circ} \mathrm{C}$. After antigen retrieval, sections were blocked for $2 \mathrm{~h}$ at room temperate in $10 \%$ normal goat serum (NGS) for polyclonal antibodies or in $10 \%$ normal horse serum for monoclonal antibodies and then incubated in the following primary antibodies: (1) monoclonal EF1 $\alpha$ antibody (dilution of 1:500; Upstate Biotechnology, Lake Placid, NY); (2) polyclonal c-fos antibody at a dilution of 1:250; (3) polyclonal phosphorylated ribosomal protein S6 (p-S6) antibody (dilution of 1:250; Cell Signaling Technology, Beverly, MA); and (4) polyclonal phosphorylated extracellular signal-regulated kinase (ERK) antibody (dilution of 1:200; Cell Signaling Technology). Sections were washed with $1 \times$ TBS several times and then incubated in biotin-conjugated secondary antibody for $2 \mathrm{~h}$ at room temperature. For the mouse monoclonal antibodies, the secondary antibody was a horse anti-mouse IgG at a dilution of 1:500. For the rabbit polyclonal antibody, the secondary antibody was goat anti-rabbit IgG at a dilution of 1:500. After washing, sections were incubated in Vector ABC kit (Vector Laboratories, Burlingame, CA) for $1 \mathrm{~h}$ and then reacted with $\mathrm{DAB}$ and $\mathrm{H}_{2} \mathrm{O}_{2}$ for the colorization reaction. Sections were mounted on poly-L-lysine slides, dehydrated through alcohols to xylene, and coverslipped.

For phalloidin staining, tissue sections were treated with PBS with $0.1 \%$ Triton X-100 for 30 min, blocked with 2.5\% BSA and 2.5\% NGS/ PBS for $2 \mathrm{~h}$, and then incubated overnight at $4^{\circ} \mathrm{C}$ with phalloidintetramethylrhodamine isothiocyanate conjugate $(0.5 \mu \mathrm{g} / \mathrm{ml}$; Sigma, St. Louis, MO).

Optical density measurements. Optical density (OD) measurements 
were taken using an M4 microcomputer imagine device. By using a $10 \times$ $10 \mu \mathrm{m}$ measuring box, a row of five separate OD measurements were taken at each level from the granule cell layer to the molecular layer, and the OD values at each level were averaged. Graphs illustrate the average OD at each level of the molecular layer.

Assessment of protein levels by Western blot. Hippocampal slices (500 $\mu \mathrm{m}$ ) were prepared from adult Sprague Dawley rats. Slices were allowed to equilibrate for $2 \mathrm{~h}$ at room temperature in artificial CSF (ACSF) saturated in $95 \% \mathrm{O}_{2}$ and $5 \% \mathrm{CO}_{2}$ containing the following (in $\mathrm{mm}$ ): 124 $\mathrm{NaCl}, 5 \mathrm{KCl}, 1.25 \mathrm{NaH}_{2} \mathrm{PO}_{4}, 26 \mathrm{NaHCO}_{3}, 1 \mathrm{MgCl}_{2}, 2 \mathrm{CaCl}_{2}$, and 10 dextrose (Gallagher et al., 2004). Then slices were treated with $50 \mu \mathrm{M}$ DHPG in ACSF for $15 \mathrm{~min}$, or slices were preincubated with $20 \mu \mathrm{M}$ anisomycin for $30 \mathrm{~min}$ before adding DHPG. Slices were frozen and stored at $-80^{\circ} \mathrm{C}$ immediately after treatment. Slices were homogenized by sonication in homogenization buffer containing the following: $50 \mathrm{~mm}$ HEPES, pH 7.4, $50 \mathrm{~mm} \mathrm{NaCl}, 1$ mм EDTA, 0.2 mм EGTA, 1 mм DTT, $0.01 \%$ SDS, $0.5 \%$ sodium deoxycholate, $1 \%$ Triton X-100, 1 mM PMSF, $10 \mu \mathrm{l} / \mathrm{ml}$ protease inhibitor cocktail (Sigma), and $10 \mu \mathrm{l} / \mathrm{ml}$ phosphatase inhibitor cocktail (Sigma). Samples containing 10-20 $\mu$ g of protein were resolved on 10\% Bis-Tris precast gels (Bio-Rad, Hercules, CA) and transferred to nitrocellulose membranes. Membranes were blocked with $4 \%$ BSA in TBST (Tris-buffered saline and Tween 20) overnight and then incubated with EF1 $\alpha$ (1:1000; Upstate Biotechnology) and phosphop44/42 mitogen-activated protein (MAP) kinase (1:1000; Cell Signaling Technology), and then the blots were stripped off and reprobed with MAP kinase 1/2 (ERK 1/2) (1:2000; Upstate Biotechnology). Blots were washed several times in 2\% BSA/TBST and then incubated in HRPconjugated secondary antibody (1:5000). Images were detected using ECL plus Western blot detection kit (Amersham Biosciences, Little Chalfont, UK). For densitometry quantification of immunopositive bands, the blots were scanned using a phosphorimager, and the bands were analyzed by ImageQuant software (Molecular Dynamics, Sunnyvale, CA). The optical densities of EF $1 \alpha$ bands were normalized to the band for total ERK.

Assessing protein synthesis by ${ }^{3} \mathrm{H}$-leucine incorporation. Adult male Sprague Dawley rats were prepared for physiology as described above, and a micropipette filled with DHPG was positioned in the hippocampus. Within $5 \mathrm{~min}$ after placing the micropipette, $0.5 \mathrm{mCi}$ of ${ }^{3} \mathrm{H}$-leucine was injected intravenously via the tail vein, and rats were perfused with paraformaldehyde $30 \mathrm{~min}$ after the injection. The brain was prepared for sectioning on a cryostat as described above. Half of the sections were mounted on slides for autoradiography (see below), and half were kept for immunostaining.

Autoradiography. Slides with sections were dried overnight at $42^{\circ} \mathrm{C}$, dehydrated, defatted through an ascending EtOH series to xylene, and rehydrated. The sections were dried and dipped in Eastman Kodak (Rochester, NY) NTB2 emulsion and stored in light-tight boxes at $5^{\circ} \mathrm{C}$ for 2-3 weeks. The slides were developed in D-19, rinsed, and fixed, and then the sections were stained with cresyl violet.

\section{Results}

\section{EF1 $\alpha$ mRNA is localized in dendrites}

In situ hybridization analyses of sections from adult rat and mouse brains revealed that the mRNA for EF1 $\alpha$ was widely expressed in many types of neurons throughout the brain. Figure $1 A$ illustrates the overall pattern of labeling in a sagittal section of mouse brain, and $B-D$ illustrate the pattern of labeling in different regions from a coronal section of rat brain. In general, larger neurons were more heavily labeled than small ones. For example, in the cerebral cortex (Fig. $1 B, E$ ), the large pyramidal neurons in layer $\mathrm{V}$ were the most heavily labeled; medium-sized neurons in layers II-III exhibited moderate labeling, and smaller neurons in layer IV and the deep cortical layers were more lightly labeled. Medium-sized neurons in the striatum exhibited relatively low levels of labeling (approximately the same as the smaller neurons in the cortex). Neurons through the piriform cortex and amygdala exhibited moderate to heavy labeling (Fig. 1C). Most neu-

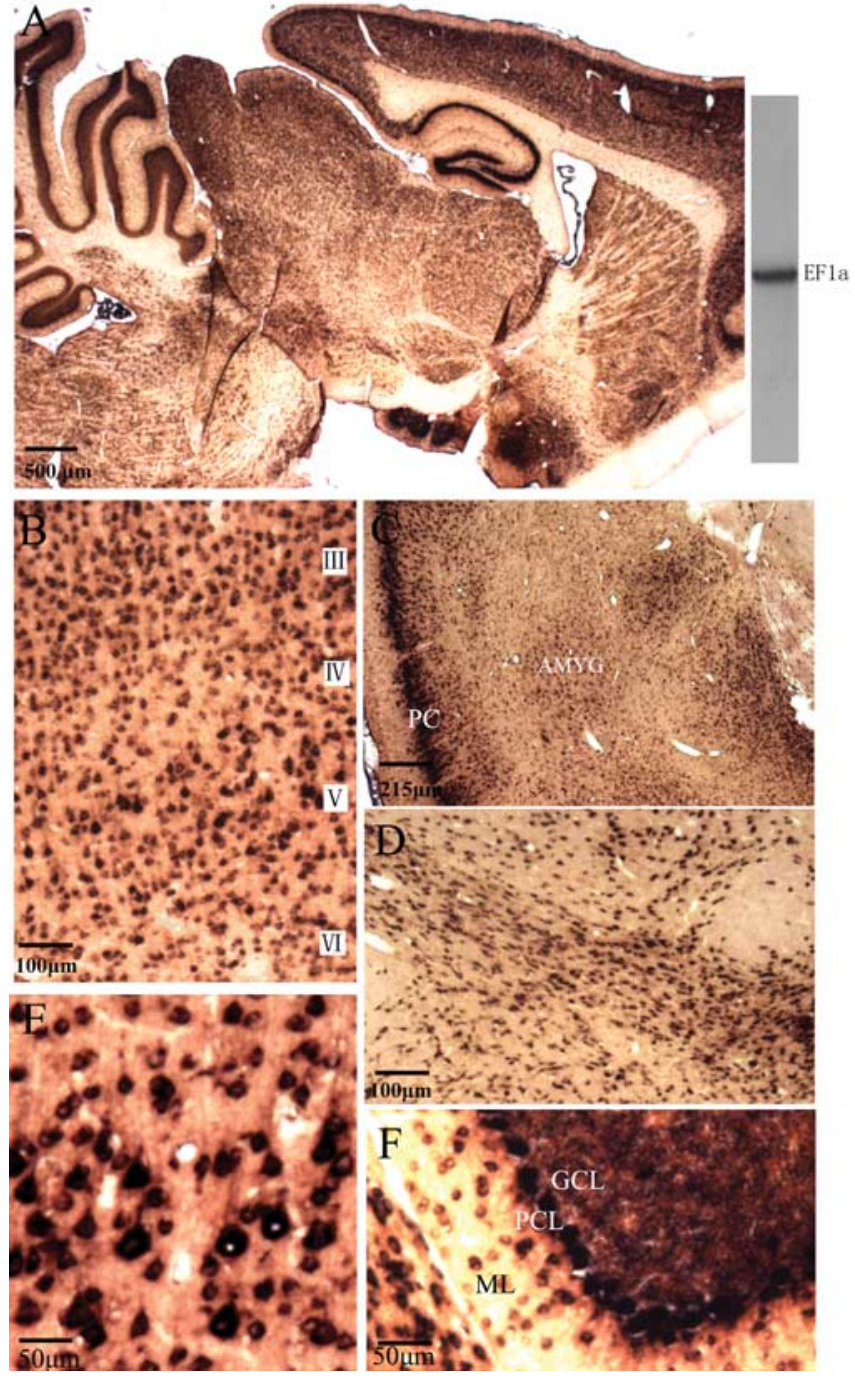

Figure 1. EF1 $\alpha$ mRNA distribution in the brain. $\boldsymbol{A}$, Overall pattern of labeling in a sagittal section of mouse brain. The panel on the right illustrates a Northern blot showing the specificity of the cRNA probe. $\boldsymbol{B}-\boldsymbol{D}$ illustrate the pattern of labeling in various regions in a coronal section of rat brain. $\boldsymbol{B}$, Cortex; $\boldsymbol{C}$, amygdala and surrounding piriform cortex; $\boldsymbol{D}$, thalamus; $\boldsymbol{E}$, cortex layer $\checkmark$ neurons. Note labeled apical dendrites extending toward the cortical surface. $\boldsymbol{F}$, Cerebellum. Note band of labeling in the inner portion of the molecular layer (which contains the proximal dendrites of cerebellar Purkinje cells). Letters in $\boldsymbol{B}$ indicate cortical layers. AMYG, Amygdala; PC, piriform cortex; PCL, Purkinje cell layer; GCL, granule cell layer; ML, molecular layer.

rons in the thalamus exhibited moderate levels of labeling (Fig. $1 D)$. In the cerebellum, Purkinje cells were heavily labeled, whereas granule cells were more lightly labeled, and the scattered interneurons in the molecular layer were moderately labeled (Fig. $1 F$ ). We did not notice that any particular neuron types were unlabeled, consistent with the fact that $\mathrm{EF} 1 \alpha$ is a ubiquitous elongation factor.

It was noteworthy that there were few labeled cells in white matter regions (Fig. 1A), indicating that $\mathrm{EF} 1 \alpha$ is expressed at low levels by oligodendrocytes. Similarly, there were very few labeled cells in the neuropil regions of laminated structures, such as the hippocampus, indicating that $\mathrm{EF} 1 \alpha$ is also not expressed at high levels by astrocytes.

Interestingly, EF1 $\alpha$ mRNA is localized in the dendrites of many neuron types. Dendritic labeling was especially obvious in laminated structures in which dendrites and neuronal cell bodies 


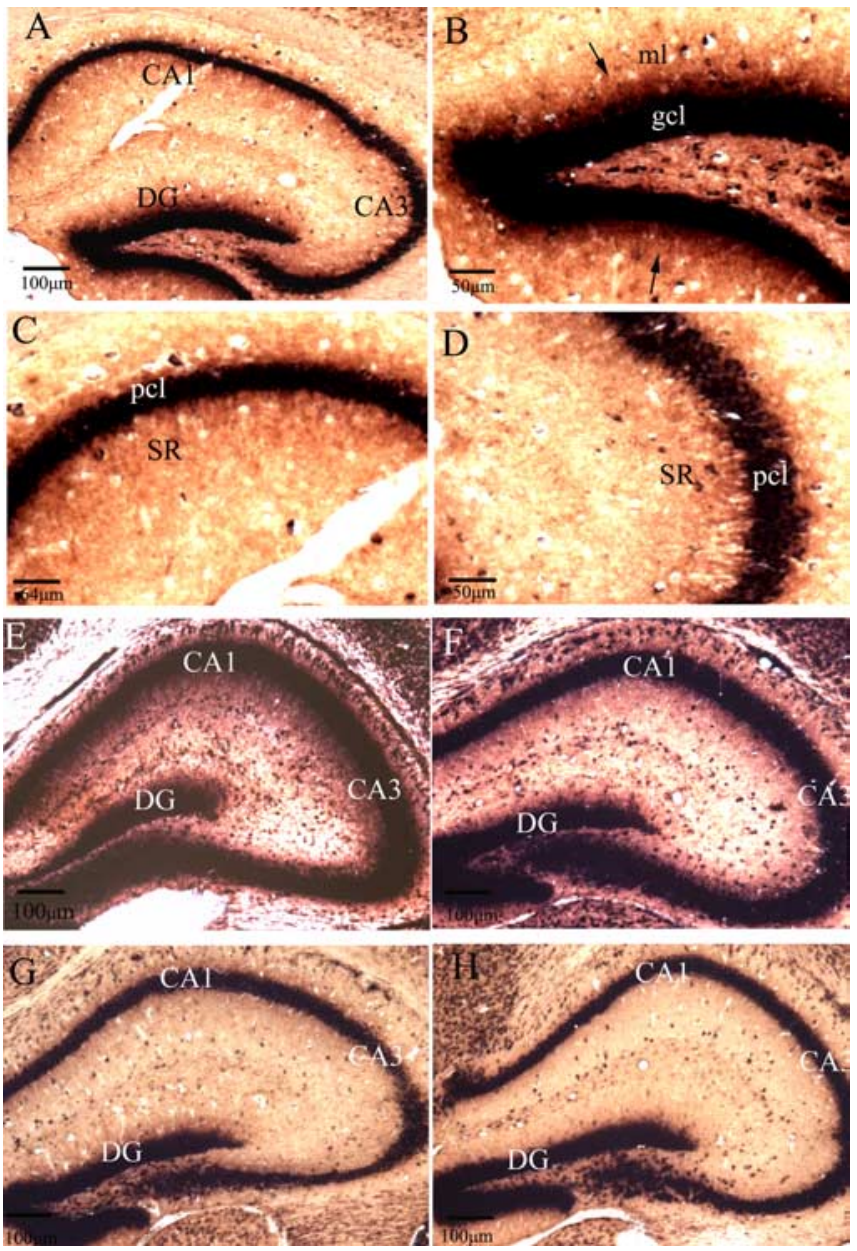

Figure 2. EF1 $\alpha$ mRNA expression in hippocampus. $A$, Overall pattern of EF $1 \alpha$ mRNA expression in the hippocampus. $\boldsymbol{B}-\boldsymbol{D}$, Higher-magnification pictures of the different regions of hippocampus. $\boldsymbol{B}$, Dentate gyrus; $\boldsymbol{C}, C$ A1 region; $\boldsymbol{D}$, CA3 region. $\boldsymbol{E}-\boldsymbol{H}$, Illustrate EF1 $\alpha$ mRNA distribution during development in mice. $\boldsymbol{E}$, Postnatal $10 \mathrm{~d} ; \boldsymbol{F}$, postnatal day $15 ; \boldsymbol{G}$, postnatal day 25 ; $\boldsymbol{H}$, postnatal day 39. DG, Dentate gyrus; $\mathrm{pcl}$, pyramidal cell layer; gcl, granule cell layer; SR, stratum radiatum; $\mathrm{ml}$, molecular layer. Small arrows in $\boldsymbol{B}$ indicate the sharp boundary of labeling at the boundary between the inner and middle molecular layers.

are present in different laminas [for example, the cerebral cortex, the hippocampus, and dentate gyrus (Fig. $2 A-D$ )]. In the cerebral cortex, labeling was evident in apical dendrites extending from the cell bodies of pyramidal neurons toward the cortical surface (Fig. 1E).

Importantly, the subcellular distribution of EF1 $\alpha$ in adult animal differs from that of other dendritic mRNAs described to date in that the mRNA is concentrated in particular dendritic laminas with sharp boundaries between laminas. Moreover, the laminas correspond to the sites of termination of particular types of synapses. This was most evident in the dentate gyrus, in which the inner molecular layer exhibited moderate labeling, but labeling stopped abruptly at the transition between the inner molecular layer (the site of termination of the commissural/associational system) and the middle molecular layer, which is the site of termination of the projections from the medial entorhinal cortex. For example, Figure 3 illustrates the correspondence between the band of labeling for EF1 $\alpha$ mRNA and a band of increased Timm's staining in the inner molecular layer, which previous studies have shown to correspond to the terminal field of the dentate commissural/associational system (Haug, 1974). In the CA1 region of the
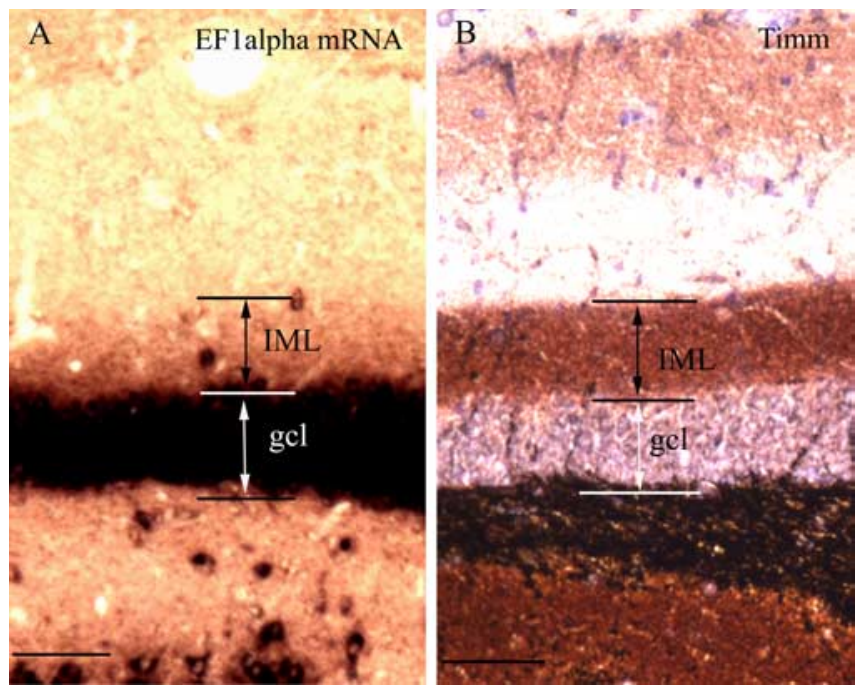

Figure 3. EF1 $\alpha \mathrm{mRNA}$ is concentrated in the inner molecular layer in dentate gyrus. $\boldsymbol{A}, \mathrm{EF} 1 \alpha$ $m R N A$ distribution in adult dentate gyrus. Arrows and bars indicate the higher levels of labeling for EF1 $\alpha$ mRNA in the inner molecular layer. $\boldsymbol{B}$, Section stained by the Timm's sulfide silver technique, illustrating the labeling pattern in the molecular layer of the dentate gyrus. The heavily labeled band in the inner molecular layer corresponds to the site of termination of the commissural/associational system (Haug, 1974). IML, Inner molecular layer; gcl, granule cell layer. Scale bars, $50 \mu \mathrm{m}$.

hippocampus, labeling for EF1 $\alpha$ mRNA was also highest in the laminas contacted by the commissural/associational system (the stratum oriens and stratum radiatum) and lower in the zone of termination of projections from the entorhinal cortex (stratum lacunosum-moleculare). In the CA1 region, however, there was no precise boundary between labeled and unlabeled laminas. The higher levels of labeling in particular dendritic laminas, and especially the precise boundary of labeling at the boundary between two different afferent systems, suggest that the intradendritic distribution of the mRNA may be related in some way to the distribution of different types of synapses.

\section{EF1 $\alpha$ mRNA is present at high levels during dendritic development}

Most dendritic mRNAs that have been assessed, including $\alpha$-calcium/calmodulin-dependent kinase II ( $\alpha$-CaMKII) mRNA and Arc mRNA, are present at low levels during development and increase in abundance as dendrites mature. In contrast, EF1 $\alpha$ mRNA was present at high levels in developing dendrites. In the hippocampus of postnatal day 10 (P10) to P15 mice, EF1 $\alpha$ mRNA was present at high levels and was localized throughout the developing dendritic laminas (Fig. 2E,F). After P25, the localization of EF1 $\alpha$ mRNA was similar to what is seen in adult animals (Fig. $2 G, H$ ). The fact that EF $1 \alpha$ mRNA is present at high levels in developing dendrites invites the speculation that local synthesis of EF1 $\alpha$ plays an important role in synaptic development.

\section{The distribution of EF1 $\alpha$ mRNA in the dentate gyrus is not} altered by activating particular sets of synapses

One possible explanation of the fact that EF $1 \alpha$ mRNA is concentrated in particular laminas is that the distribution of the mRNA is determined by signals generated by different types of synapses. The best characterized example of afferent regulation of mRNA distribution in dendrites involves the mRNA for Arc, which ac- 


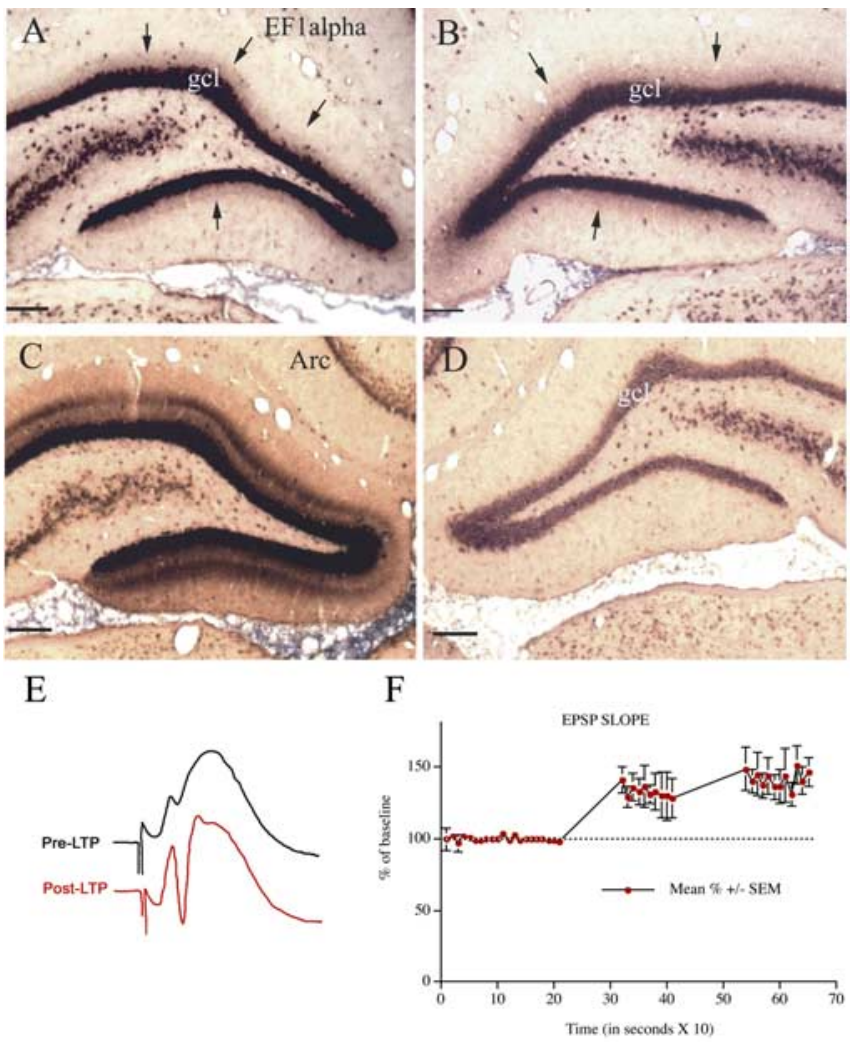

Figure 4. EF1 $\alpha$ mRNA distribution is not altered after prolonged periods of high-frequency stimulation of the perforant pathway. $\boldsymbol{A}, \mathrm{EF} 1 \alpha$ mRNA distribution in the dentate gyrus after $2 \mathrm{~h}$ of high-frequency stimulation of the perforant pathway. $\boldsymbol{B}$, EF1 $\alpha$ mRNA distribution on the side contralateral to the stimulation. $C$, Arc mRNA expression in the stimulated dentate gyrus. Arrow points out the activated dendritic lamina. $\boldsymbol{D}$, Arc mRNA expression on the control side. Small arrows in $\boldsymbol{A}$ and $\boldsymbol{B}$ indicate the sharp boundary of labeling at the boundary between the inner and middle molecular layers. Scale bars, $100 \mu \mathrm{m}$. $\boldsymbol{E}$, Illustrates perforant path evoked responses before (Pre-LTP) and after (Post-LTP) the third bout of 10 high-frequency trains. After determining the degree of potentiation, trains were delivered at a rate of $1 / 10 \mathrm{~s}$ for $2 \mathrm{~h}$. $\boldsymbol{F}$, The graph illustrates the average \pm SEM EPSP potentiation seen in three representative animals that are illustrated in subsequent figures. gcl, Granule cell layer.

cumulates in activated dendritic laminas in response to repeated bouts of high-frequency synaptic activation (Steward and Worley, 2001a). For example, when the pathway from the medial entorhinal cortex to the middle dendritic layer of the dentate gyrus (the medial perforant pathway) is activated using stimulation paradigms that induce LTP, Arc mRNA expression is strongly induced, and the mRNA migrates into dendrites. If the stimulation is continued as the mRNA migrates into dendrites, Arc mRNA localizes in the activated dendritic laminas (in this case, the middle molecular layer). Moreover, stimulation for as little as $15 \mathrm{~min}$ is sufficient to cause a dramatic relocalization of Arc mRNA that is already in dendrites as a result of previous induction (Steward and Worley, 2001a). To determine whether these stimulation paradigms alter the distribution of EF1 $\alpha$ mRNA, we stimulated the pathway from the medial entorhinal cortex to the middle dendritic layer of the dentate gyrus (the medial perforant pathway) for $5 \mathrm{~min}$ (which is sufficient to induce LTP), $15 \mathrm{~min}, 30 \mathrm{~min}, 1 \mathrm{~h}$, and $2 \mathrm{~h}$. There was no detectable change in the distribution of EF $1 \alpha$ mRNA after any of the stimulation regimens, however. For example, Figure $4 \mathrm{~A}$ illustrates the distribution of EF $1 \alpha$ mRNA after $2 \mathrm{~h}$ of highfrequency stimulation; the pattern of labeling on the con- tralateral side is shown for comparison (Fig. $4 B$ ). In the same tissue, however, the stimulation triggered Arc mRNA induction and caused the expected targeting of newly synthesized Arc mRNA to the activated dendritic lamina (Fig. 4, compare $C, D)$. Figure $4 E$ illustrates the EPSP potentiation that occurred in response to the stimulation in the animal illustrated in Figure $4 A-D$ (top trace, baseline; bottom trace, response after the third bout of 10 high-frequency trains). The graph in Figure $4 F$ illustrates the average EPSP potentiation seen in three representative animals that are illustrated in subsequent figures.

\section{Metabotropic glutamate receptor activation triggers local synthesis of EF1 $\alpha$ protein in dendrites}

The presence of EF1 $\alpha$ mRNA in dendrites provides a potential substrate for local synthesis of EF $1 \alpha$ protein. The key question, however, is whether the translation of the mRNA is induced by events involved in protein synthesis-dependent synaptic plasticity. Accordingly, we determined whether EF1 $\alpha$ protein levels were increased after treatments that induce LTD (by metabotropic glutamate receptor activation) or LTP (by high-frequency stimulation of the perforant pathway).

Activation of mGluRs by DHPG elicits a LTD of synaptic transmission at excitatory synapses onto hippocampal CA1 pyramidal cells (Huber et al., 2000; Huber et al., 2001) and dentate granule cells (Camodeca et al., 1999). Accordingly, it was of interest to evaluate whether local delivery of DHPG into the dendritic laminas of the hippocampus and dentate gyrus would trigger local synthesis of EF1 $\alpha$ protein.

Figure $5 A$ illustrates an experiment in which a micropipette filled with DHPG was positioned in the distal dendritic lamina of CA1 and the animal was killed after $30 \mathrm{~min}$. There was a striking increase in immunostaining for EF1 $\alpha$ protein in dendrites surrounding the micropipette tip. Levels of immunostaining were highest in the part of the dendrite nearest the tip of the micropipette and extended along the dendrite for several hundred micrometers (Fig. 5A). Some of the dendrites exhibiting increased staining could be followed to their cell body of origin, and, interestingly, the levels of immunostaining in the cell body were not noticeably higher than in other nearby cells. Also evident were interneurons with increased $\mathrm{EF} 1 \alpha$ expression in the cell bodies and dendrites in the DHPG diffusion area (Fig. $5 B$ ).

In other experiments, small volumes $(0.2 \mu \mathrm{l})$ of DHPG were injected from a Hamilton microsyringe fitted with pulled glass micropipette tips. These local injections also induced increases in immunostaining for $\mathrm{EF} 1 \alpha$ in the areas surrounding the injection sites. For these experiments, a recording lead was connected to the barrel of the microsyringe to record evoked responses generated by stimulation of the entorhinal cortex or contralateral hippocampus. We found that the local injections of small volumes $(0.2 \mu \mathrm{l})$ of either saline or DHPG usually caused substantial instability in evoked potential amplitude and often caused brief seizures (data not shown). In most cases, evoked potential amplitude decreased immediately after the injections and remained depressed throughout the recording period. Because of the response instability that occurred after both saline and DHPG injections, it was difficult to reliably monitor the physiological effects of DHPG per se (for example, whether the injection induced LTD). Because the local injections often caused seizures and response instability, we focused on the paradigm involving diffusion from a blunt-tipped micropipette.

Importantly, the increases in immunostaining for $\mathrm{EF} 1 \alpha$ induced by DHPG were completely blocked by pretreatment with 


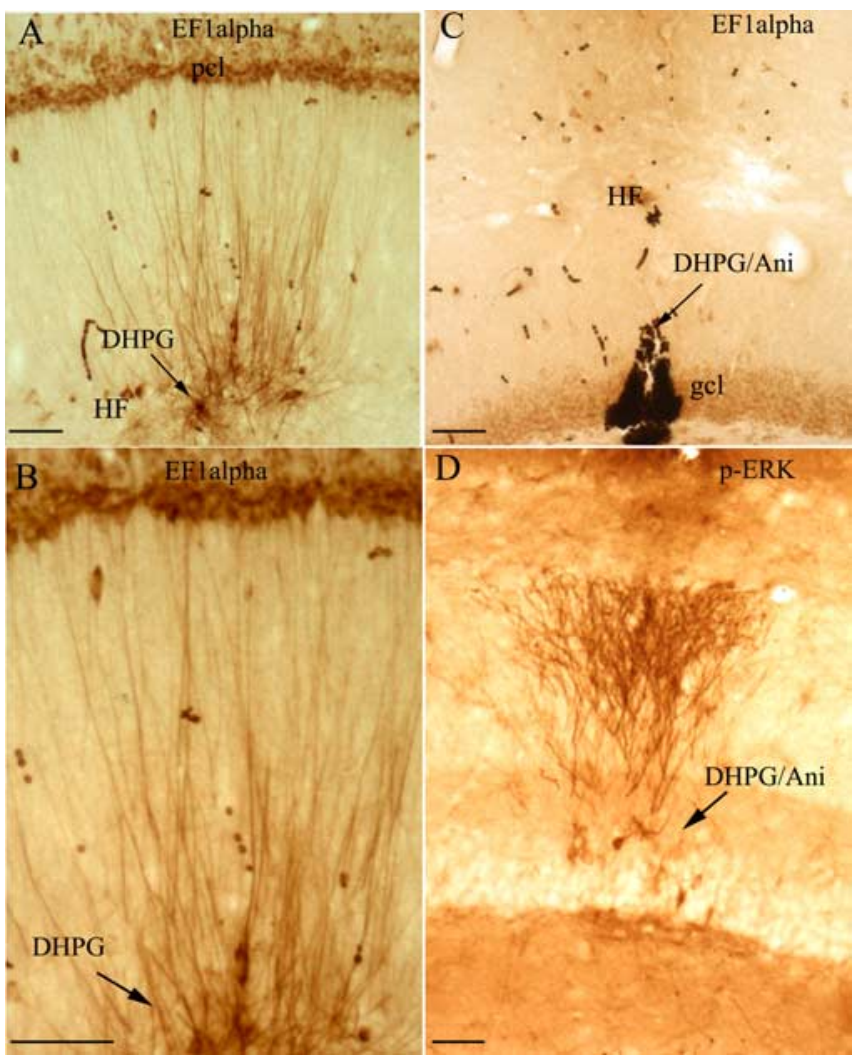

Figure 5. Local application of DHPG triggers a dramatic increase in EF1 $\alpha$ protein levels in dendrites. $A$, The photomicrograph illustrates the striking increases in immunostaining for EF1 $\alpha$ protein in dendrites surrounding a DHPG-filled micropipette (30 min after placement of the micropipette). $\boldsymbol{B}$, High-power view of EF1 $\alpha$ protein increase in the dendrites, which shows increased staining of dendrites with minimal if any increases in immunostaining at the level of the cell body, documenting that the increases in EF1 $\alpha$ protein occur locally in dendrites. $C$, Increases in immunostaining for EF1 $\alpha$ are blocked by systemic injection of the protein synthesis of anisomycin. Note the complete lack of any increase in dendritic staining in the area surrounding the micropipette. $D$, As a positive control for the efficacy of DHPG, a nearby section was immunostained for $p$-ERK. Note striking increases in p-ERK staining in the area surrounding the DHPG-filled micropipette in the DHPG/anisomycin experiment. Arrows indicate the path of the DHPG-filled micropipette. Scale bars, $50 \mu \mathrm{m}$. DHPG/Ani, DHPG/anisomycin; gcl, granule cell layer; HF, hippocampal fissure; $\mathrm{pcl}$, pyramidal cell layer.

protein synthesis inhibitors. For example, Figure $5 C$ illustrates an experiment in which the protein synthesis inhibitor anisomycin $(100 \mathrm{mg} / \mathrm{kg}$ ) was injected subcutaneously $30 \mathrm{~min}$ before the insertion of the DHPG-filled micropipette. In this experiment, the micropipette was positioned in the dentate gyrus, and there was no evidence of increased immunostaining for EF1 $\alpha$ in nearby dendrites. Similar results were seen in two other animals that had been pretreated with anisomycin. As a positive control for the effect of DHPG, nearby sections were stained for p-ERK, which is activated by DHPG (Roberson et al., 1999; Berkeley and Levey, 2003). In animals that had been pretreated with anisomycin, there were striking increases in immunostaining for $\mathrm{p}$-ERK in the area surrounding the micropipette but no increase in immunostaining for EF1 $\alpha$ (Fig. 5, compare $C, D$ ).

We also assessed whether mGluR activation by DHPG caused any alteration in the distribution of EF $1 \alpha$ mRNA. In situ hybridization analyses revealed no detectable alterations in the localization of EF1 $\alpha$ mRNA in the same cases described above in which levels of EF1 $\alpha$ protein were induced (data not shown).

\section{Treatment known to induce LTD triggers EF1 $\alpha$ protein} synthesis in hippocampal slices

One protocol for chemical induction of LTD in the CA1 region involves treating hippocampal slices with DHPG (Huber et al., 2000). Based on the results above, it was thus of considerable interest to determine whether applications of DHPG that induced LTD also triggered increases in EF1 $\alpha$ synthesis in slices. When hippocampal slices were treated with DHPG in the same way that has been shown to reliably induce LTD and harvested 15 min after treatment for quantitative Western blot analysis, EF1 $\alpha$ protein levels increased in the DHPG-treated hippocampal slices (Fig. 6A). Quantitative analysis of four independent experiments showed an average increase of $37 \pm 8.5 \%$ compared with the untreated control ( $p<.02$ by paired $t$ test). In the same blots, immunostaining using antibodies that recognize p-ERK revealed that ERK phosphorylation was also induced in the treated slices (by $\sim 110 \pm 2.69 \%$ ) (Fig. 6A), as described previously (Roberson et al., 1999; Berkeley and Levey, 2003; Gallagher et al., 2004). Pretreatment of hippocampal slices with the protein synthesis inhibitor anisomycin $(20 \mu \mathrm{M}) 30$ min before DHPG treatment completely blocked the increase in EF1 $\alpha$ protein levels (DHPG, $101.15 \pm 2.22 \%$; control, $100 \% ; n=3$ ), demonstrating that the increases in $\mathrm{EF} 1 \alpha$ protein levels were attributable to protein synthesis.

\section{Increases in EF1 $\alpha$ protein levels in dendrites are not accompanied by detectable increases in overall translational capacity}

$\mathrm{EF} 1 \alpha$ is a critical component of the translational machinery, and so the increases in EF1 $\alpha$ protein after DHPG treatment could increase overall translational capacity in local dendritic compartments (Bailey et al., 2004; Kelleher et al., 2004a). To test this hypothesis, EF1 $\alpha$ synthesis was induced by local application of DHPG as above, and protein synthetic activity in the area of the injection was assessed by measuring ${ }^{3} \mathrm{H}$-leucine incorporation autoradiographically. Consistent with previous studies using similar methodology, grain density was highest in the laminas containing neuronal cell bodies, with lower levels of labeling in the dendritic laminas. There was no evidence of higher grain density in the area exhibiting increased EF1 $\alpha$ protein levels, however (Fig. $6 B, C$ ). These experiments reveal that the increases in EF1 $\alpha$ levels do not signal a dramatic increase in translational capacity in dendritic laminas. It remains possible that there is a modest increase in translational capacity in individual dendrites that would not be detectable by autoradiographic measurements of overall protein synthesis in the dendritic laminas.

\section{Induction of LTP causes an increase in immunostaining for EF1 $\alpha$ protein in the activated dendritic lamina in the dentate gyrus that is not dependent on protein synthesis}

Previous studies have provided evidence that induction of LTP triggers a local synthesis of certain proteins whose mRNAs are present in dendrites at high levels, including MAP2 and $\alpha$-CaMKII (Ouyang et al., 1999; Steward and Halpain, 1999). For example, high-frequency activation of perforant path projections led to increases in immunostaining of $\alpha$-CaMKII in the activated dendritic lamina and increases in MAP2 immunostaining in lamina immediately adjacent to the activated synapses (Steward and Halpain, 1999). Accordingly, it was of interest to determine whether the same patterns of synaptic activation would increase the level of immunostaining for $\mathrm{EF} 1 \alpha$ in the activated dendrites.

After high-frequency stimulation of the perforant pathway, a sharply defined band of increased immunostaining appeared in 
A

DHPG Control

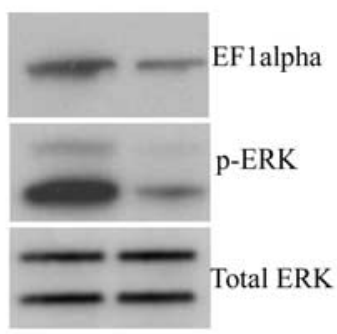

Figure 6. DHPG treatment of hippocampal slices triggers rapid increases in EF1 $\alpha$ protein synthesis and no overall protein synthesis increase by measuring ${ }^{3} \mathrm{H}$-leucine incorporation autoradiographically. $A$, Western blot illustrating levels of EF1 $\alpha$, $\mathrm{p}$-ERK, and ERK in DHGP-treated and control hippocampal slices. $\boldsymbol{B},{ }^{3} \mathrm{H}$ incorporation in the DHPG diffusion area in the CA1 region. $\boldsymbol{C}$, EF1 $\alpha$ protein increase in the dendrites of CA1 in the DHPG diffusion area. Arrows point out the path of DHPG-filled micropipette. Scale bars, $50 \mu \mathrm{m}$.

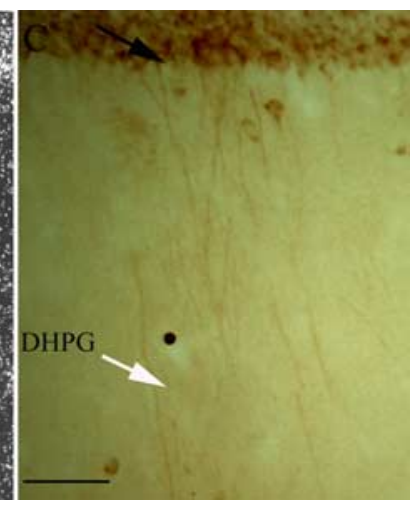

tern of immunostaining after $30 \mathrm{~min}$ and $2 \mathrm{~h}$ of stimulation, respectively). Figure $4 \mathrm{C}$ illustrates the distribution of Arc mRNA in the same case of $2 \mathrm{~h}$ stimulation to show the correspondence between the band of $\mathrm{EF} 1 \alpha$ and the band of Arc mRNA.

To obtain a quantitative measure of the alterations in immunostaining, OD measurements were taken across the granule cell layer and molecular layer. After $30 \mathrm{~min}$ of high-frequency stimulation, levels of immunostaining were higher throughout the molecular layer on the stimulated side (Fig. $7 B, E$ ). Interestingly, levels of immunostaining were lower over the cell body lamina (granule cell layer). After $2 \mathrm{~h}$ of stimulation, overall levels of immunostaining were actually lower on the stimulated side, and on each side of the
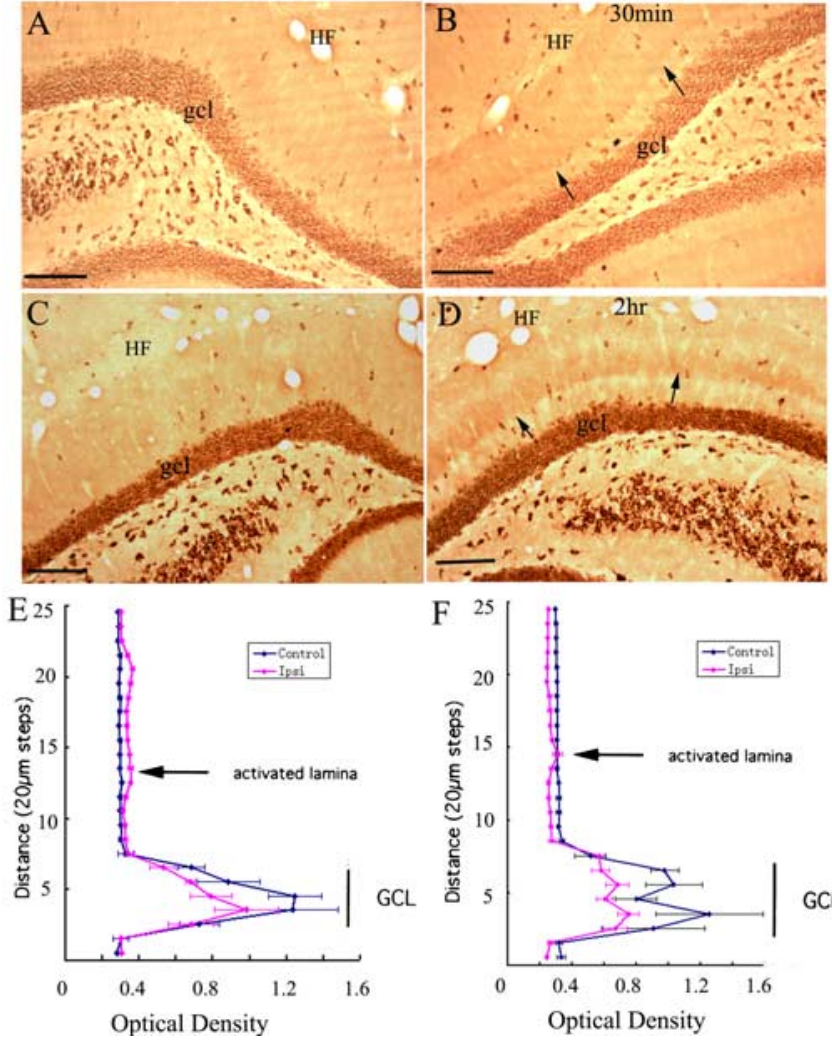

Figure 7. High-frequency stimulation of the medial perforant pathway alters immunostaining patterns for EF1 $\alpha$ in the activated dentate gyrus. $A$, Pattern of immunostaining in the dentate gyrus on the side contralateral to the stimulation. $\boldsymbol{B}$, Pattern of immunostaining after 30 min of high-frequency stimulation of the perforant path; small arrows indicate the band of increased immunostaining in the middle molecular layer (the site of termination of the medial perforant path). C, Pattern of immunostaining for EF1 $\alpha$ on the control side of an animal that received $2 \mathrm{~h}$ of high-frequency stimulation. $\boldsymbol{D}$, Pattern of immunostaining after $2 \mathrm{~h}$ of highfrequency stimulation. The graphs in $\boldsymbol{E}$ plot the average $\mathrm{OD}$ of $\mathrm{EF} 1 \alpha$ immunostaining across the molecular layer from the cases illustrated in $\boldsymbol{A}$ and $\boldsymbol{B}$, after $30 \mathrm{~min}$ of high-frequency stimulation, and $\boldsymbol{F}$ is the case illustrated in $\boldsymbol{C}$ and $\boldsymbol{D}$, after $2 \mathrm{~h}$ of high-frequency stimulation. Error bars indicate the SD of the five measurements at each level. HF, Hippocampal fissure; gcl, granule cell layer. Arrows point to the activated dendritic lamina. Scale bars, $100 \mu \mathrm{m}$.

the activated dendritic lamina of the dentate gyrus (Fig. 7). The band of increased immunostaining for EF $1 \alpha$ was detectable after 15 min stimulation (data not shown) and appeared more distinct after longer periods of stimulation (Fig. $7 B, D$ illustrates the pat- band of relatively higher staining in the activated lamina was an area of distinctly decreased immunostaining in both inner and outer molecular layers, which contain proximal and distal dendrites, respectively (Fig. 7D). OD measurement confirmed a sharp peak in the activated dendritic lamina and decreases in immunostaining in inner and outer molecular layers compared with the control side (Fig. 7F). Again, levels of immunostaining were also lower in the cell body lamina on the stimulated side.

\section{Increases in $\mathrm{EF} 1 \alpha$ immunostaining in activated lamina are not blocked by protein synthesis inhibitors}

The most obvious explanation for the band of increased immunostaining is a local synthesis of $\mathrm{EF} 1 \alpha$ protein, especially given the results above with DHPG treatment that induced a local synthesis of $\mathrm{EF} 1 \alpha$. To address this question, a micropipette recording electrode filled with the protein synthesis inhibitor anisomycin $(30 \mathrm{mg} / \mathrm{ml})$ was positioned in the dentate gyrus during the period of synaptic activation. As shown previously (Steward and Halpain, 1999), the inhibitor diffuses from the micropipette, blocking protein synthesis in a small area. The area of blockade can be demonstrated by immunostaining for the immediate early gene c-fos, which is strongly induced by the stimulation; this increase in c-fos protein levels is blocked in the area surrounding the micropipette (Steward and Halpain, 1999) (Fig. 8D). To our surprise, inhibiting protein synthesis did not prevent the appearance of the band of increased immunostaining for $\mathrm{EF} 1 \alpha$ (Fig. $8 B$ ). Similarly, we tested the effect of rapamycin, which has been shown to selectively inhibit translation of mRNAs encoding elongation factors and ribosomal proteins, including EF1 $\alpha$ mRNA (Terada et al., 1994; Jefferies et al., 1994), and again local injections of rapamycin into the dentate gyrus did not block the increases in EF1 immunostaining in the activated dendritic lamina (Fig. $8 \mathrm{~F}$ ). As a positive control for the effectiveness of rapamycin, we took advantage of the fact that the stimulation paradigm used here also causes increases in immunostaining for the phosphorylated form of ribosomal protein S6; these increases were blocked in the area surrounding the rapamycin injection (Fig. $8 H$ ). Together, these results suggest that the increase in immunostaining for $\operatorname{EF} 1 \alpha$, although visually striking, is most consistent with a redistribution of $\mathrm{EF} 1 \alpha$ protein to the activated dendrites rather than an overall increase in $\mathrm{EF} 1 \alpha$ protein levels attributable to de novo synthesis. 

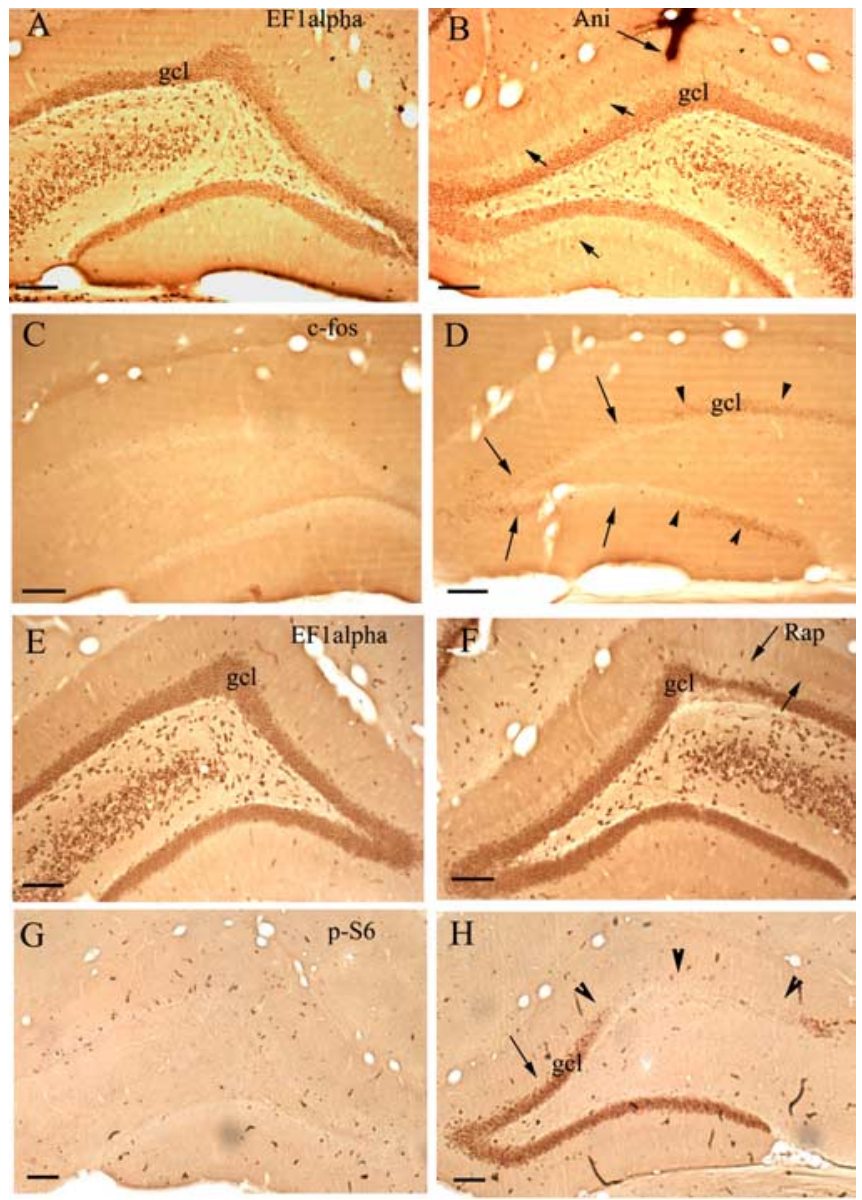

Figure 8. EF1 $\alpha$ immunostaining pattern alteration induced by LTP stimulation in the dentate gyrus is not blocked by the protein synthesis inhibitors anisomycin or rapamycin. $\boldsymbol{A}$ and $\boldsymbol{B}$ illustrate EF1 $\alpha$ immunostaining on the control side $(\boldsymbol{A})$ and on the stimulated side $(\boldsymbol{B})$ with anisomycin in the micropipette. Small arrows indicate the band of increased immunostaining. $C$ and $\boldsymbol{D}$ illustrate $\mathbf{c}$-fos immunostaining on the control side $(\boldsymbol{C})$ and stimulated side $(\boldsymbol{D})$. Arrows indicate regions in which c-fos immunostaining is increased; arrowheads indicate the area of blockade in which c-fos is present at control levels. $\boldsymbol{E}$ and $\boldsymbol{F}$ illustrate EF1 $\alpha$ immunostaining on the control side $(\boldsymbol{E})$ and stimulated side $(\boldsymbol{F})$ with rapamycin injection. $\boldsymbol{G}$ and $\boldsymbol{H}$ illustrate immunostaining for $\mathrm{p}-\mathrm{S} 6$ on the control side $(\boldsymbol{G})$ and the stimulated side $(\boldsymbol{H})$ with rapamycin injection. Arrows indicate cells exhibiting increased immunostaining for $\mathrm{p}-\mathrm{S6}$; arrowheads indicate the site of rapamycin injection. Ani, Anisomycin; gcl, granule cell layer; Rap, rapamycin. Scale bars, $100 \mu \mathrm{m}$.

\section{Increases in EF1 $\alpha$ immunostaining in the activated lamina are} blocked by the actin polymerization inhibitor latrunculin $B$

In addition to its role as an elongation factor, $\mathrm{EF} 1 \alpha$ also has been shown to bind actin, and there is evidence that the interaction between $\mathrm{EF} 1 \alpha$ and actin is critical for anchoring $\beta$-actin mRNA to the cytoskeleton (Liu et al., 2002). This is of considerable interest because previous studies have shown a dramatic increase in filamentous actin (F-actin) after induction of LTP in the perforant path (Fukazawa et al., 2003). Accordingly, it was of interest to determine whether the alterations in $\mathrm{EF} 1 \alpha$ immunostaining were blocked by latrunculin, which interferes with actin polymerization. Again, we used the strategy of including the relevant drug, in this case latrunculin $\mathrm{B}$, in the recording micropipette while delivering high-frequency stimulation to the perforant pathway. Consistent with previous reports (Fukazawa et al., 2003), high-frequency stimulation of the perforant pathway led to dramatic increases in staining for filamentous actin in the
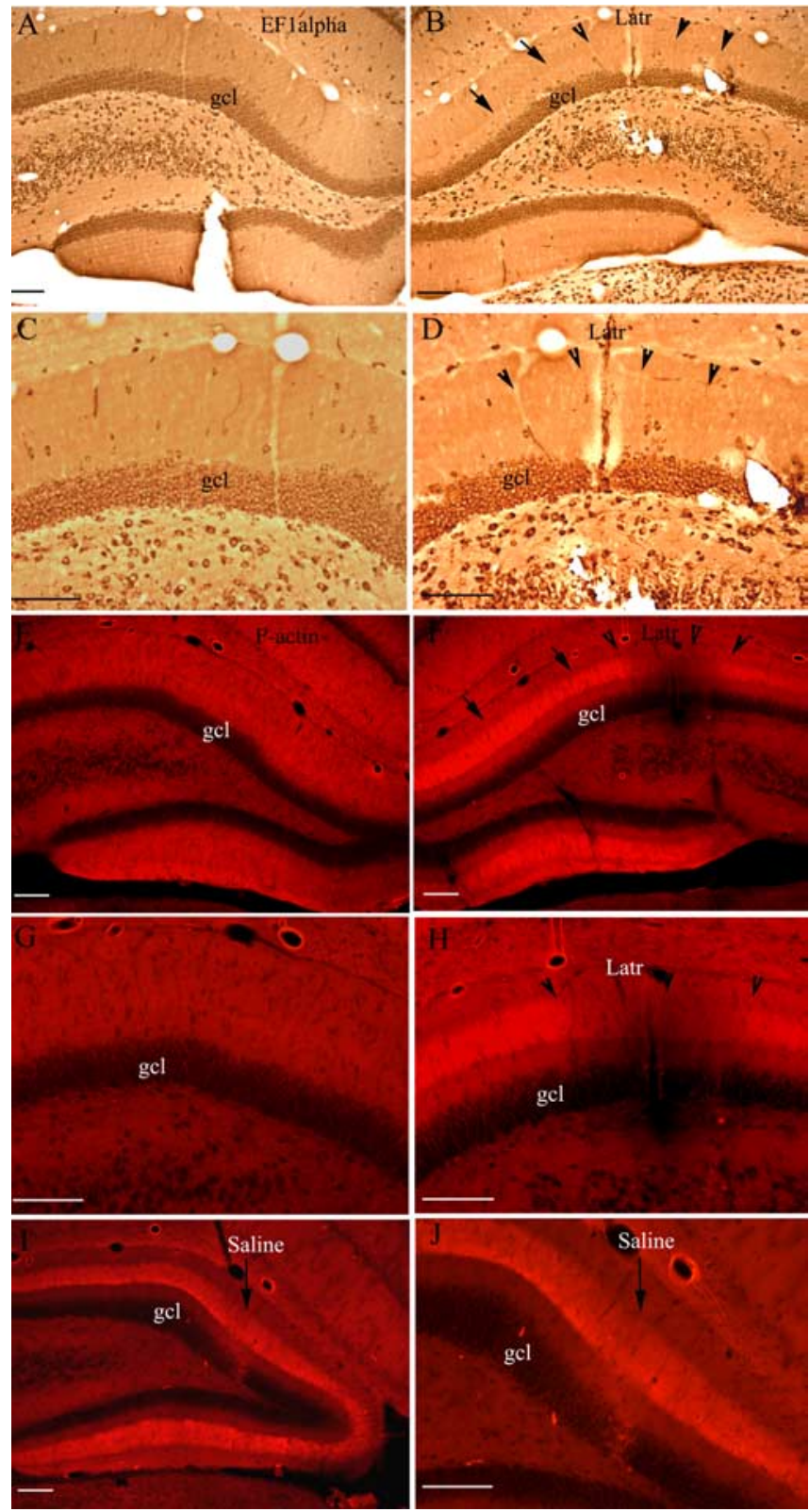

Figure 9. EF1 $\alpha$ immunostaining increase in the activated dendritic lamina induced by LTP stimulation is blocked by the actin polymerization inhibitor latrunculin B. A-D show the immunostaining for EF1 $\alpha$. $A$ and $C$ illustrate the side contralateral to the high-frequency stimulation. $\boldsymbol{B}$ and $\boldsymbol{D}$ illustrate the stimulated side with latrunculin $B$ drug application. Arrows indicate the band of increased EF1 $\alpha$ immunostaining in the stimulated dentate gyrus; arrowheads point out the blockade of the band by latrunculin B. $\boldsymbol{E}-\boldsymbol{H}$ show the phalloidin staining of F-actin with a section close to the section shown in $\boldsymbol{B}$. Arrows indicate the band of increased F-actin in the stimulated dentate gyrus; arrowheads point out the blockade of the band by latrunculin B. I and $J$ show the phalloidin staining of F-actin with brain sections that received LTP stimulation with only saline in the electrode. The presence of the saline electrode has no effect on the band of the F-actin, as indicated by the arrows. gd, Granule cell layer; Latr, latrunculin B. Scale bars, $100 \mu \mathrm{m}$.

activated laminas as revealed by phalloidin staining (Fig. 9F,I), and these increases were blocked in a region surrounding a micropipette containing latrunculin B (Fig. 9F, $H$ ). Immunostaining of an adjacent section for EF1 $\alpha$ revealed that the band of increased staining was blocked in approximately the same region as the blockade of actin polymerization (Fig. 9B,D). Figure 9, $I$ and $J$, shows that the saline electrode has no effect on the band of F-actin in the dentate gyrus after LTP stimulation. 


\section{Discussion}

The present results demonstrate that the mRNA for $\mathrm{EF} 1 \alpha$, a critical component of translational machinery, is present constitutively in the dendrites of many neuron types, including neurons in the forebrain that exhibit protein synthesis-dependent LTP and LTD. The mRNA is concentrated in portions of the dendrite contacted by particular types of synapses, suggesting some degree of synaptic control on dendritic localization. Nevertheless, the distribution of the mRNA is not altered after prolonged periods of synaptic activation. Treatment with the mGluR agonist DHPG causes a local increase in immunostaining for $\mathrm{EF} 1 \alpha$ protein levels in dendrites of hippocampal neurons in vivo and increases in EF1 $\alpha$ protein levels in hippocampal slices, which are blocked by inhibiting protein synthesis. Nevertheless, the increases in EF1 $\alpha$ protein were not accompanied by detectable increases in protein synthetic capacity in the dendritic lamina. Although intense synaptic activation sufficient to induce LTP causes local increases in immunostaining for $\mathrm{EF} 1 \alpha$ protein, these increases are probably not attributable to new protein synthesis and instead may reflect a redistribution of existing EF $1 \alpha$ protein, which may be related to the reorganization of the actin cytoskeleton. Together, these results document that local translation of the mRNA for EF $1 \alpha$ in dendrites is regulated by mGluR-mediated signal transduction events that lead to LTD. In what follows, we will discuss each of these points in turn.

\section{EF1 $\alpha$ mRNA is localized in dendrites and concentrated in dendritic domains that are contacted by particular types of synapses}

EF1 $\alpha$ mRNA is present constitutively in dendrites, providing a substrate for local translation in response to signals from synapses. The distribution of EF1 $\alpha$ mRNA differs from that of other known dendritic mRNAs, however, in that it is concentrated in dendritic zones that are contacted by particular types of synapses, inviting the speculation that the distribution of EF $1 \alpha$ mRNA is regulated by synaptic signaling. An obvious possibility is that localization is regulated by synaptic activity, but one test of this hypothesis, involving high-frequency activation of the perforant path that is sufficient to alter the dendritic localization of Arc mRNA (Steward and Worley, 2001a), did not alter EF1 $\alpha$ mRNA distribution. Thus, if the localization of EF1 $\alpha$ mRNA in particular dendritic laminas is determined by signals from synapses, the process is either slower than is the case for Arc mRNA (so that it would not be seen with $2 \mathrm{~h}$ of stimulation), occurs in response to different kinds of synaptic signals than does Arc mRNA, or the signals mediating localization may be generated by synaptic contact rather than synaptic activity.

Our results do not exclude the possibility that synaptic activation causes a more local change in the localization of EF $1 \alpha$ mRNA (for example, causing it to move from the dendrite into the spine or vice versa), as has been reported for ribosomes (Ostroff et al., 2002) and other dendritic mRNAs (Havik et al., 2003). Our experiments would not have detected this sort of local redistribution. It also remains possible that the distribution of EF $1 \alpha$ mRNA will be altered by other manipulations of synaptic activity.

In terms of synaptic regulation of the dendritic localization of EF1 $\alpha$ mRNA, it is noteworthy that the mRNA is present at high levels throughout dendrites early in development (for example at $\mathrm{P} 10$ and P15). Thus, the developmental profile of EF $1 \alpha$ expression in dendrites is opposite to that of other dendritic mRNAs, which increase in abundance as neurons mature. P7-P15 is a time of extensive dendritic growth and rapid synaptogenesis (Steward et al., 1996; Fiala et al., 1998), but is also a time at which overall synaptic density is low (especially at P7) (Steward et al., 1996). Thus, dendritic localization of EF $1 \alpha$ mRNA is highest when overall synapse density (and thus presumably synaptic signaling) is low.

\section{Translation of EF1 $\alpha$ mRNA is regulated by mGluR signaling}

Local delivery of DHPG into dendritic lamina caused a dramatic increase in dendritic immunostaining for EF1 $\alpha$ protein, and treatment of hippocampal slices with DHPG in a way that has been shown to reliably induce LTD triggers substantial increases in EF1 $\alpha$ protein levels. Both effects were blocked by pretreatment with anisomycin. The fact that activation of mGluRs triggers both a local translation of EF $1 \alpha$ mRNA and protein synthesisdependent LTD invites the speculation that local synthesis of $\mathrm{EF} 1 \alpha$ protein plays a role in the synaptic changes underlying LTD.

Interestingly, stimulation sufficient to induce LTP also causes striking alterations in immunostaining for EF1 $\alpha$ protein in the activated dendritic lamina, but these are not blocked by either anisomycin or rapamycin. Thus, the band of increased immunostaining for EF1 $\alpha$ may not reflect local protein synthesis. Nevertheless, it should be noted that protein synthesis inhibitors also do not block the appearance of a band of increased staining for CAMKII protein (Steward and Halpain, 1999), although other evidence strongly suggests that synaptic activity does trigger CAMKII protein synthesis (Ouyang et al., 1999; Havik et al., 2003). One possible explanation for the lack of blockade of CAMKII synthesis by protein synthesis inhibitors is that CAMKII mRNA is weakly initiated, and its translation is actually enhanced by low concentrations of protein synthesis inhibitors that block the translation of other mRNAs (Scheetz et al., 2000). We cannot exclude the possibility that the same is true for $\mathrm{EF} 1 \alpha$, and that the band of increased staining after the induction of LTP actually does reflect local protein synthesis.

Another possible explanation, however, for the band of immunostaining after high-frequency stimulation of the perforant path is a redistribution of $\mathrm{EF} 1 \alpha$ protein that is already present consequent to reorganization of the actin cytoskeleton. In support of this possibility, local delivery of latrunculin B did block the band of EF1 $\alpha$ immunostaining after LTP, which demonstrates that the appearance of the band is related to the reorganization of the actin cytoskeleton. Conversely, a band of increased immunostaining for EF1 $\alpha$ was seen after only 15 min of stimulation, at which time there was no decrease in immunostaining in adjacent laminas. This suggests that the initial appearance of the band of increased immunostaining is not attributable to a redistribution of EF1 $\alpha$ protein and may actually reflect some de novo synthesis of EF1 $\alpha$ protein. The decrease in immunostaining after more prolonged stimulation may reflect a protein redistribution or protein degradation, so that multiple mechanisms may be operating.

\section{Does local synthesis of EF1 $\alpha$ increase translational capacity in dendrites?}

The central role of EF1 $\alpha$ is in protein translation as an elongation factor; thus, local increases in EF1 $\alpha$ protein provide a potential mechanism for upregulating translational capacity in local dendritic compartments (Bailey et al., 2004). The present results indicate that this idea, first established through studies of mRNAs in neurites of Aplysia neurons, is also plausible for mammalian neurons. This is of considerable interest because it has been suggested that induction of both LTP and LTD strongly activate translational machinery within neurons (Kelleher et al., 2004a). 
The fact that local synthesis of EF1 $\alpha$ protein is induced by activation of mGluRs is consistent with other evidence that induction of mGluR-dependent LTD induces dendritic mRNA translation without new transcription (Huber et al., 2000). Thus, the increase in $\mathrm{EF} 1 \alpha$ expression in dendrites after $\mathrm{mGluR}$ activation could be a mechanism underlying an enhanced translational capacity during the induction of this form of LTD.

At the same time, however, our autoradiographic analyses revealed no evidence of detectable increase in protein precursor incorporation in areas exhibiting increased levels of EF1 $\alpha$ protein. Although autoradiography may not be sufficiently sensitive to detect relatively small increases in translational capacity, it would have revealed massive increases in dendritic protein synthesis that have been predicted to occur in response to signals that induce LTD (Kelleher et al., 2004a). Thus, the increase in EF1 $\alpha$ protein may be important for something other than regulating translational capacity in dendrites.

In addition to its role as an elongation factor, there is evidence that $\mathrm{EF} 1 \alpha$ protein may play a critical role in linking $\beta$-actin mRNA and associated translational machinery to the actin cytoskeleton (Liu et al., 2002). These findings raise the intriguing possibility that the increases in EF1 $\alpha$ protein that are triggered by mGluR activation may be critical for linking certain mRNAs and associated translational machinery to particular actin-rich subcellular microdomains. One possible domain is the network of filamentous actin that is prominent in the neck of spines. Another is the postsynaptic density, which contains actin and also has been shown to contain EF1 $\alpha$ protein (Cho et al., 2004). Local translation at the postsynaptic density is of considerable interest because it represents a potential mechanism for cotranslational assembly of newly synthesized proteins into multi-molecular signaling complexes at the synapse (for discussion, see Steward and Worley, 2001b).

The increases in immunostaining for EF $1 \alpha$ protein after highfrequency stimulation of the perforant path occur in exactly the same lamina in which there are dramatic increases in filamentous actin, consistent with the hypothesis that $\mathrm{EF} 1 \alpha$ protein interacts with filamentous actin. Moreover, the increase in immunostaining for EF $1 \alpha$ is blocked by the actin depolymerizing drug latrunculin B. Given the fact that EF1 $\alpha$ protein is capable of linking mRNAs to the actin cytoskeleton, it is noteworthy that the increases in EF1 $\alpha$ protein occur in exactly the same lamina in which newly synthesized Arc mRNA accumulates (Steward and Worley, 2001a). Again, these facts invite the speculation that the increase in EF1 $\alpha$ staining and increases in filamentous actin are part of the mechanism underlying the docking of mRNAs in the activated dendritic lamina. Conversely, the ability of $\mathrm{EF} 1 \alpha$ to bind to the actin cytoskeleton may be important for the function of the protein in actin-rich structures, including dendritic spines or the postsynaptic density. It is also possible that $\mathrm{EF} 1 \alpha$ may participate in the regulation of the adjustments of the actin cytoskeleton in response to synaptic activity, which are likely to be critical for the morphological alterations that accompany LTP. Additional experiments will be required to explore these possibilities.

\section{References}

Bailey CH, Bartsch D, Kandel ER (1996) Toward a molecular definition of long-term memory storage. Proc Natl Acad Sci USA 93:13445-13452.

Bailey CH, Kandel ER, Si K (2004) The persistence of long-term memory-a molecular approach to self-sustaining changes in learning-induced synaptic growth. Neuron 44:49-57.

Berkeley JL, Levey AI (2003) Cell-specific extracellular signal-regulated kinase activation by multiple $G$ protein-coupled receptor families in hippocampus. Mol Pharmacol 63:128-135.
Bliss TV, Collinridge GL (1993) A synaptic model of memory: long-term potentiation in the hippocampus. Nature 361:31-39.

Camodeca N, Breakwell NA, Rowan MJ, Anwyl R (1999) Induction of LTD by activation of group I mGluR in the dentate gyrus in vitro. Neuropharmacology 38:1579-1606.

Cho SJ, Jung JS, Ko BH, Jin I, Moon IS (2004) Presence of translation elongation factor-1A (eEF1A) in the excitatory postsynaptic density of rat cerebral cortex. Neurosci Lett 366:29-33.

Fiala JC, Feinberg M, Popov V, Harris KM (1998) Synaptogenesis via dendritic filopodia in developing hippocampal area CA1. J Neurosci 18:8900-8911.

Fukazawa Y, Saitoh Y, Ozawa F, Ohta Y, Mizuno K, Inokuchi K (2003) Hippocampal LTP is accompanied by enhanced F-actin content within the dendritic spine that is essential for late LTP maintenance in vivo. Neuron 38:447-460.

Gallagher SM, Daly CA, Bear MF, Huber KM (2004) Extracellular signalregulated protein kinase activation is required for metabotropic glutamate receptor-dependent long-term depression in hippocampal area CA1. J Neurosci 24:4859-4864.

Giustetto M, Hegde AN, Si K, Casadio A, Inokuchi K, Pei W, Kandel ER, Schwartz JH (2003) Axonal transport of eukaryotic translation elongation factor lalpha mRNA couples transcription in the nucleus to longterm facilitation at the synapse. Proc Natl Acad Sci USA 100:13680-13685.

Haug F-MS (1974) Light microscopical mapping of the hippocampal region, the pyriform cortex and the corticomedial amygdaloid nuclei of the rat brain with Timm's sulphide silver method. I. Area dentata, hippocampus, and subiculum. Z Anat Entwickl-Gesch 145:1-27.

Havik B, Pokke H, Bardsen K, Davanger S, Bramham CR (2003) Bursts of high-frequency stimulation trigger rapid delivery of pre-existing $\alpha$-CaMKII mRNA to synapses: a mechanism in dendritic protein synthesis during long-term potentiation in adult awake rats. Eur J Neurosci 17:2679-2689.

Huber KM, Kayser MS, Bear MF (2000) Role of rapid dendritic protein synthesis in hippocampal mGluR-dependent long-term depression. Science 288:1254-1256.

Huber KM, Roder JC, Bear MF (2001) Chemical induction of mGlR5- and protein synthesis-dependent long-term depression in hippocampal area CA1. J Neurophysiol 86:321-325.

Jefferies HBJ, Reinhard C, Kozma SC, Thomas G (1994) Rapamycin selectively represses translation of the polypyrimidine tract mRNA family. Proc Natl Acad Sci USA 91:4441-4445.

Kandel ER (2001) The molecular biology of memory storage: a dialogue between genes and synapses. Science 294:1030-1038.

Kelleher III RJ, Govindarajan A, Tonegawa S (2004a) Translational regulatory mechanisms in persistent forms of synaptic plasticity. Neuron 44:59-73.

Kelleher III RJ, Govindarajan A, Jung HY, Kang H, Tonegawa S (2004b) Translational control by MAPK signaling in long-term synaptic plasticity and memory. Cell 116:467-479.

Kindler S, Rehbein M, Classen B, Richter D, Bockers TM (2004) Distinct spatiotemporal expression of SAPAP transcripts in the developing rat brain: a novel dendritically localized mRNA. Brain Res Mol Brain Res 126:14-21.

Liu G, Grant WM, Persky D, Latham VM, Singer RH, Condeelis J (2002) Interactions of elongation factor $1 \alpha$ with $\mathrm{F}$-actin and $\beta$-actin mRNA: implications for anchoring mRNA in cell protrusions. Mol Biol Cell 13:579-592.

Ostroff LE, Fiala JC, Allwardt B, Harris KM (2002) Polyribosomes redistribute from dendritic shafts into spines with enlarged synapses during LTP in developing rat hippocampus slices. Neuron 35:535-545.

Ouyang Y, Rosenstein A, Kreiman G, Schuman EM, Kennedy MB (1999) Tetanic stimulation leads to increased accumulation of $\mathrm{Ca}^{2+} /$ calmodulin-dependent protein kinase II via dendritic protein synthesis in hippocampal neurons. J Neurosci 19:7823-7833.

Roberson ED, English JD, Adams JP, Selcher JC, Kondratick C, Sweatt JD (1999) The mitogen-activated protein kinase cascade couples PKA and PKC to cAMP response element binding protein phosphorylation in area CA1 of hippocampus. J Neurosci 19:4337-4348.

Scheetz AJ, Nairn AC, Constantine-Paton M (2000) NMDA receptormediated control of protein synthesis at developing synapses. Nat Neurosci 3:211-216. 
Steward O, Halpain S (1999) Lamina-specific synaptic activation causes domain-specific alteration in dendritic immunostaining for MAP2 and $\alpha$-CaMKII. J Neurosci 19:7834-7845.

Steward O, Schuman EM (2003) Compartmentalized synthesis and degradation of proteins in neurons. Neuron 40:347-359.

Steward O, Worley PF (2001a) Selective targeting of newly synthesized Arc mRNA to active synapses requires NMDA receptor activation. Neuron $30: 227-240$

Steward O, Worley PF (2001b) A cellular mechanism for targeting newly synthesized mRNAs to synaptic sites on dendrite. Proc Natl Acad Sci USA 98:7062-7068.

Steward O, Falk PM, Torre ER (1996) Ultrastructural basis for gene expres- sion at the synapse: synapse-associated polyribosome complexes. J Neurocytol 25:717-734.

Steward O, Wallace CS, Lyford GL, Worley PF (1998) Synaptic activation causes the mRNA for the IEG Arc to localize selectively near activated postsynaptic sites on dendrites. Neuron 21:741-751.

Terada N, Patel HR, Takase K, Kohno K, Nairn AC, Gelfand EW (1994) Rapamycin selectively inhibits translation of mRNAs encoding elongation factors and ribosomal proteins. Proc Natl Acad Sci USA 91:11477-11481.

Welch JM, Wang D, Feng G (2004) Differential mRNA expression and protein localization of the SAP90/PSD-95-associated proteins (SAPAPs) in the nervous system of the mouse. J Comp Neurol 472:24-39. 